\title{
Identification of Eco-friendly Practices in the Industries of EGREE Region for Sustainable Development, Andhra Pradesh, India
}

\author{
Teki Surayya*1 ,Gudivada Rajendra Prasad², Arigela Srinivasa Rao ${ }^{2}$, Jetti Ravisankar'2, \\ Matcha Johar Krishna², Indukuri Satyanarayana Raju ${ }^{2}$ \\ 1 Professor Department of Commerce and Management Studies, AdikaviNannaya University, Rajahmundry-533296, Andhra \\ Pradesh, India \\ 1.Assistant Professor, Department of Commerce and Management Studies, AdikaviNannaya University, Rajahmundry-533296,
}

ARTICLE INFORMATION

Article history:

Received:

Revised:

Accepted:

Keywords:

EGREE, eco-friendly, industry, green, pollution

tekisunny@gmail.com

\begin{abstract}
This study has been conceived with the basic objective to investigate the role played by industries in the East Godavari River Estuarine Ecosystem (EGREE) region to reduce the level of industrial pollution and other eco-friendly initiatives taken for eco-friendly and sustainable development. Effluent treatment systems prevalent in the majority of the studied industries are in working conditions. $57 \%$ of industries' effluent treatment plants are working conditions, $29 \%$ of the industries are using landing filling methods for disposal of agro-based waste. There is a strong common understanding among the EGREE region industries to lower the $\mathrm{CO} 2$ footprint by substituting coal consumption with bio-fuel. In some companies like ITC, biofuel consumption is $80 \%$, and the remaining $20 \%$ is Coal. Government and policymakers have to make provision for industrial waste disposal, especially for small and medium enterprises (SME). Waste transporting cost is high for SME. Effluent treatment plant (ETP) and sewage treatment plant (STP) conditions to be verified by the pollution control board periodically.
\end{abstract}

(C)2020 


\section{INTRODUCTION}

Industrial pollution is an issue has risen from the annals of esoteric scientific discussion in the 70's and 80's to the coffee table discussions in the late 90's. This industrial pollution is due to unsustainable and ecological destructive practices of industries that are causing many problems including climate change that has come about because of increased awareness and concern among people. Increase of carbon content in the atmosphere is a primary cause of IP as a consequence of deforestation and atmospheric pollution. People have come to understand the long term effect of IP. A survey by Roper Strarch Worldwide (Ottman, 1998), conducted primarily in the USA, reported the top ten very serious environmental concerns of the consumers as 1)industrial water pollution, 2)destruction of ozone, 3)destruction of rain forest, 4)industrial accidents, 5)hazardous waste 6)oil spills, 7)industrial air pollution, 8)radiation from nuclear power plant accidents, 9)drinking water contamination, and 10)ocean contamination.

However in Indian context in the absence of any such report major environmental and forest degradation can be classified as having been caused by industrial or on industrial source. Industrial sources are water, air, and ground pollution caused as a result of industrial activity. Non-industrial sources are carbon release due to deforestation, atmospheric pollution from use of manufactured goods such as automobile emissions, pollution from other non industrial activities such as sewage disposal etc., Automobiles in India account for a lion's share of non industrial environmental pollution. Atmospheric pollution from this source has become severed in the 90's as the number of automobiles in India has increased exponentially. According to a study (www.greencarcongress.com) the level of $\mathrm{NO} 2$ concentration in New Delhi ranged from 70 to 102 microgram per cubic meter in the first week of February 2005, whereas the standard limit is 80 microgram per cubic meter. During the same period in 2002 his figure ranged from 72 to 85 microgram per cubic meter. The phenomenal growth in automobile in India is directly related to economic growth and hence growth in disposable income with people. However this should not mean that we remain oblivious of the damage to environment. For example, Gandhi (1998) expressed that development that leads to the destruction of environment runs the risk of destroying itself. He added further that conserving the environment must be a focus of development in order to reap the fruits of development. Thus, IP must find ways to reduce pollution directed by improving technology, and indirectly by sequencing carbon through restoration of forests, that requires financial outlays.Industrial eco friendly activities can be grouped into a) raw material preparation stage(e.g. paperindustry undertaking its own plantations on wastelands) b) processing stage (e.g. i. efficient technologies, ii. Sourcing renewable energy, iii. Green buildings iv. E-commerce, ERP c) General practices i) Rainwater water harvesting, II) tree plantation in around the factory /office, iii)employees and consumer education programmes.

Identification of industrial eco friendly practices is comprehensive process as it contains number of components as mentioned above. All of these identified /flagged through industrial field survey with the help of define schedule/questionnaire. Identification of industrial eco friendly practices is useful to support conservations policies.

Hence, the study was done with the prime object of identification of performance of the industries in EGREE Region. As such investigation is aimed to identify the required eco-friendly practices in selected environmental concerns.

1. To diagnose and analyze the implementation ecofriendly practices in connection with industrial wastages.

2. To examine the green cover practices of industries

3. To find out the renewable energies utilization practices in industries

4. To appreciate the progress of environmental protection awareness programs of industries.

5. To analyze the corporate social responsibility (CSR) activities of industries inter alia special provision for forestry sector.

6. To benchmark innovative and creative eco-friendly practices in industries. 


\section{RESEARCH METHODOLOGY}

For production activities to be sustainable there is a need for integration of organizational objectives with environmental goals. EGREE (East Godavari River Estuarine Ecosystem) is established to accomplish this end with aid of MoEF (Ministry of Environment and Forest) Govt of India and GEF (Global Environment Facility). EGREE aims to remove key barriers to mainstreaming environmental management considerations into major production activities.

Current research was undertaken in industries operating in the East Godavari district of Andhra Pradesh to identify the levels of engagement of industries in activities that are essential for achieving the environmental goals. For this research teams were deputed to various industries to observe the physical conditions existing in each of these industries. A structured questionnaire is used to obtain the views and intent of management towards waste management, commitment towards 3R's and other environmental related issues.

\section{Research Design}

Research design used for the data collection consisted of three stages. After the list of Industries in the EGREE region had been identified, telephonic contacts were made the officials of those industries. The purpose of the research and need for data collection and scope of research activities were explained to the chief of the industry for getting the permission to visit their factory. In this process any limitations imposed by the officials were honored in the best interest of internal security and confidentiality. Taking of photos inside the industries and various machineries are strictly prohibited, hence research honored their rules and regulations. However such limitations did not limited the current research work at any stage.

In Stage two, a team of 4 members visited each of these factories at various dates to gather the data on selected issues that needed to be addressed by the industries in EGREE region for sustainable and balanced environmental and ecological balance. Physical observation of existing facilities is done in this stage. Appointments are also fixed with HR manager / Pollution control / CSR Heads in the selected entity.
In Stage three, the same team of 4 members are divided into two teams of 2 members each. One team collected primary information on interview basis. Such discussion is mostly unstructured because questions are framed by the investigators based on the responses of the interviewee. Information on voluntary initiatives, CSR initiatives and innovative methodologies adapted by certain enterprises is obtained by investigators. The other teams collected data based on a structured questionnaire. Such information is essential for analysis of factors on which industry eco-friendly practices are dependent.

\section{Primary and secondary sources of data}

This report is mainly developed based on primary data sources derived from questionnaire and interviews with concerned officials. Data gathered from primary sources is suitably tabulated and pie charts are used for diagrammatic expression of the existing situation. Analysis these tables provided the basis for interpretation of possible reasons for underperformance of any class of industry in respect of eco-friendly practices. Such results are cross checked with opinions of environmental offers expressed in interviews. Factor dependence tests are also conducted in respect of prominent factors to cross check the interpretations.

Secondary sources of data are mainly taped for the review of literature. Considerable research work already done at national and international levels, were reviewed to identify the research gaps and provide the required innovation in the current research work. Secondary sources shall include various publication of EGREE and MoEF as accessed from web sources.

\section{Hypothesis tested}

H01: The ability of the industry to honor the Ecofriendly practices is independent of the nature of Industry. In other words an entity can follow Ecofriendly practices irrespective of its nature (or) type.

H11: The ability to honor Eco-friendly practices is not unique for all industries in EGREE region. It depends on type of industry to which it belongs.

H02: The ability of the industry to honor the Ecofriendly practices is independent of the size of Industry. In other words an entity can follow Eco-friendly practices irrespective of its it is large scale or small scale. 
H12: The ability to honor Eco-friendly practices is not unique for all industries in

\section{Statistical tools applied for the study}

Data is tabulated to compute the percentage of performance in each of the selected dimension by 28 industries in EGREE region. Use of percentages had the advantage of universal understandability and ready basis for interpretations. Considering the independence of industries due to the differences in ownership, capital base and nature basis, averages and standard deviations cannot be applied.

However, to get confirmation of interpretations, chisquare test for independence of attributes is applied for prominent factors.

\section{RESULTS AND DISCUSSIONS}

Out of the selected sample of 28 industries, it was identified that need for dumping away from human dwellings was applicable to only 7 industries in the sample. Thus $75 \%$ of industries are not having the dumping obligation. As seen from above tabulation, 6 Industries have performed their obligation completely

Table 1. Performance of industries in dumping of solid wastes away from human dwellings.

\begin{tabular}{lcc}
\hline & $\begin{array}{c}\text { Number of } \\
\text { Industries }\end{array}$ & $\begin{array}{c}\text { Percentage } \\
(\%)\end{array}$ \\
\hline Completely & 6 & 21 \\
Partly & 1 & 4 \\
Yet to Start & 0 & 0 \\
Not Applicable & 21 & 75 \\
Total & 28 & 100 \\
\hline
\end{tabular}

while one industry had done it partially.

Effluent treatment systems existing in the select industries are in good working condition in majority of industries. Only one industry was found to have effluent treatment system in poor working condition. Above table and graph indicates that $57 \%$ of industries had effluent treatment plants working in good conditions. Out of the 28 industries surveyed, 11 industries are not obliged to maintain an effluent treatment plant.

Observations indicate that $29 \%$ of the industries are using the land filling method for disposal of agro based
Table 2.Working condition of effluent treatment system

\begin{tabular}{llllll}
\hline & Good & Average & Poor & NA & Total \\
\hline $\begin{array}{l}\text { Number of } \\
\begin{array}{l}\text { Industries } \\
\text { Percentage }\end{array}\end{array}$ & 16 & 0 & 1 & 11 & 28 \\
\hline
\end{tabular}

wastage. Land filling method converts the waste into manure for use in Agro industry. Thus these 8 industries

Table 3. Usage of land filling method

\begin{tabular}{lcccc}
\hline & Yes & No & NA & Total \\
\hline $\begin{array}{l}\text { Number of } \\
\text { Industries. }\end{array}$ & 8 & 2 & 18 & 28 \\
Percentage & 29 & 7 & 64 & 100 \\
\hline
\end{tabular}

are completely recycling the waste generated by them. However, there are 2 industries which comprise $7 \%$ of sample are not recycling there waste. The remaining 18 industries (64\%) are non-agro industries, hence

Table 4. Plastic and non-plastic waste segregation

\begin{tabular}{lcc}
\hline & $\begin{array}{c}\text { Number of } \\
\text { Industries }\end{array}$ & $\begin{array}{c}\text { Percentage } \\
(\%)\end{array}$ \\
\hline $\begin{array}{l}\text { Complete } \\
\text { Segregation }\end{array}$ & 12 & 43 \\
$\begin{array}{l}\text { Partial } \\
\text { Segregation }\end{array}$ & 0 & 0 \\
No & 5 & 18 \\
Segregation & 11 & 39 \\
$\begin{array}{l}\text { Not } \\
\text { Applicable }\end{array}$ & 28 & 100 \\
Total & & \\
\hline
\end{tabular}

recycling of waste is not applicable them.

In respect of segregation of plastic and non-plastic wastage, 12 industries were found using methods to completely segregate the waste into plastic and nonplastic waste. Observations also indicate that there are 5 industries are not segregating the waste before disposal. For remaining 11 industries segregation is not applicable as they may be either agro based industries or plastic waste is in highly negligible quantity. 
Observations indicate that 3R's (Reduce, Recycle and Reuse of waste) principle is followed and significant progress being achieved by 11 industries. Among these ITC Egree business division and Sarvaraya sugars bottling unit are prominent among them. It is also found that 3 industries including Sri papers Ltd, Godavari edible bran oil Ltd are yet to make a significant progress but still 3 R's principle is applied in these industries.

Table 5.Progress on 3R Principle

\begin{tabular}{lllll}
\hline & $\begin{array}{l}\text { Significant } \\
\text { Progress }\end{array}$ & $\begin{array}{l}\text { Some } \\
\text { Progress }\end{array}$ & $\begin{array}{l}\text { Not } \\
\text { Applicable }\end{array}$ & Total \\
\hline $\begin{array}{l}\text { Number of } \\
\text { Industries }\end{array}$ & 11 & 3 & 14 & 28 \\
Percentage & 39 & 11 & 50 & 100 \\
\hline
\end{tabular}

There 14 more industries where $3 \mathrm{R}$ 's principle is not applicable. This is due to the fact that there is either no significant waste being generated or it is sold directly to buyers who inturn use it for their own purposes. Thus recycling is indirectly done by those buyers, facts of which are not in the scope of current study.

Table 6. Companies following a select green model

\begin{tabular}{llll}
\hline & Yes & No & Total \\
\hline Number of Industries & 0 & 28 & 28 \\
Percentage & 0 & 100 & 100 \\
\hline
\end{tabular}

As seen from the above table, none of the select industries had adapted institutional models developed for industries to go green. It may be noted that these industries had their own method to contribute to green cover. Physical observations indicates, Coromandel Fertilizers Ltd, GSK Ltd and Sri Lalitha Rice, had made a very significant contribution towards development of green cover in and out of the factory premises. They are also found to have engaged in the public parks in the nearby places. Some other industries are also engaged in similar activities including plantation along the national highways and surrounding villages.

Table 8Awareness programs conducted at organization level

\begin{tabular}{lllll}
\hline & Regularly & Moderately & Never & Total \\
\hline $\begin{array}{l}\text { Number of } \\
\text { Industries }\end{array}$ & 16 & 5 & 7 & 28 \\
Percentage & 57 & 18 & 25 & 100 \\
\hline
\end{tabular}

Table 7Companies using solar energy conserving system

\begin{tabular}{cccc}
\hline & Yes & No & Total \\
\hline $\begin{array}{c}\text { Number of } \\
\text { Industries }\end{array}$ & 3 & 25 & 28 \\
Percentage & 11 & 89 & 100 \\
\hline
\end{tabular}

Study revealed that out of 28 Industries only three industries were using solar energy systems to generate power for administrative and other selected purposes.

Such industries include, Coromandel, GSK and ITC established solar panels in their business premises to substitute conventional energy conservation. Such practice not only helps to energy conservation but also reduces emersion of $\mathrm{GHG}$ and contributes to the reduction of global warming. Remaining 25 Industries had not yet adopted solar energy systems in their factories. The major hurdle is mainly due to capital expenditure needs in acquiring the solar panels and batteries and shortage of maintenance crew in the factory.

Above table and graph indicates that majority of industries are conducting the awareness programs on need for being eco-friendly and measures to be taken and followed by employees to promote the entities aims and principles towards environment. Out of 28 industries there are 16 industries which are regularly conducting the awareness programs in their organization. Prominent among such organizations were, International papers Ltd, Rajahmundry, NFCL Kakinada and GSK in Dowleswaram. Thus 57\% of the industries survey in EGREE region are very keen on achieving environmental objectives. There are 5 industries organizing the awareness programs on random manner. Such proportion is $18 \%$ of total industries investigated. Remaining 7 industries responded that they had never performed any such activity to motivate the employees towards environmental commitments. Many of these belongs to Agro-Industries where impact on environment by such industry is negligible. 
Table 9.CSR activities by different industries

\begin{tabular}{ll}
\hline Particulars of CSR Activity & Number of Industries \\
\hline Tree Plantation & 12 \\
Education & 14 \\
Health & 7 \\
Public Amenities & 7 \\
Potable water & 8 \\
\hline
\end{tabular}

As seen from above analysis, most of the industries are contributing to the education, followed by plantation of trees as a part of their CSR initiatives. Many industries are engaged in multiple activities, hence we have total number of industries in excess of 28 , i.e total industries surveyed. Thus 48 activities were found to be performed by 28 industries in the EGREE region which indicates an Activity engagement ratio $=48 / 28=1.71$ per

Table 10Response on controlling pollution by antismog devices

\begin{tabular}{lll}
\hline & Yes & No \\
& & \\
\hline No. of Industries & 0 & 28 \\
Percentage & 0 & 100 \\
\hline
\end{tabular}

industry.

It is observed that antismog devices technology is yet to start in the industries studied. However most of the industries are reducing pollution by their own means.

Industries are not allowing the vehicle beyond the point within the premises, select vehicles of the industry is only allowed to move within the industry.

These measures are taken to ensure controlled pollution within the factory premises. Above numbers indicate that none of the industries in EGREE region as surveyed
Table 11. Response on reduction of thermal \& noise pollution

\begin{tabular}{lllll}
\hline & $\begin{array}{l}\text { Significant } \\
\text { Progress }\end{array}$ & $\begin{array}{l}\text { Some } \\
\text { Progress }\end{array}$ & $\begin{array}{l}\text { No } \\
\text { progress }\end{array}$ & Total \\
\hline $\begin{array}{l}\text { No. of } \\
\text { Industries } \\
\text { Percentage }\end{array}$ & 57.16 & 8 & 4 & 28 \\
& & 28.57 & 14.28 & 100 \\
\hline
\end{tabular}

is found to be implementing antismog devices in their factory premises but they have their selected techniques to provide controlled pollution within the factory.

From the study most of the industries are confirming that they have been following strict rules in reducing the thermal and noise pollution and also in optimising power consumption. GSK, Coromandel, ITC, Sarvaraya sugars

bottlingunit,Srilalitha rice, Sri Venkatrama Oil Indpvt ltd, Sri Ramadas paper ltd,NCS industries, is among the top in reducing the thermal and noise pollution.M/s chVeerraju\& co, Sri papers, reported that with moderate care in reducing pollution.

Sri Ramalingeswara paper products pvt ltd and others are yet to take necessary steps in reducing pollution.

Table 12Response on environmental protection education in the organization

\begin{tabular}{lllll}
\hline & $\begin{array}{l}\text { Significant } \\
\text { Progress }\end{array}$ & $\begin{array}{l}\text { Some } \\
\text { Progress }\end{array}$ & $\begin{array}{l}\text { No } \\
\text { progress }\end{array}$ & Total \\
\hline $\begin{array}{l}\text { No. of } \\
\text { Industries }\end{array}$ & 18 & 6 & 4 & 28 \\
Percentage & 64 & 22 & 14 & 100 \\
\hline
\end{tabular}


Industries are taking necessary care in educating the employees towards the environmental protection.Sri

Table 13. Response on capital related problems in maintaining environmental measures

\begin{tabular}{lll}
\hline & Yes & No \\
\hline No. of Industries & 23 & 5 \\
Percentage & 82 & 18 \\
\hline
\end{tabular}

Ramadas paper 1td, Sri Lalitha, Sarvaraya sugars bottling unit, ITC, Coromandel, GSK,Gemini Edible oils, Godavari edible bran oil ltd are significantly in progress towards the environmental education in the organization.Sri Ramalingeswara paper products pvt ltd, Manihamsa power projects pvt ltd are at no progress level reported. There are 18 industries constituting 64\% of total industries in the region are providing adequate education on need for protection of environment. Study also reavels that there are 6 industries $(22 \%)$ had carried out such programs to certain extent but not on reguar basis or not of having a significant impact factor for such programs. At the same time we also have 4 industries in small scale sector that could not affored the expenditure on such programmes.

Capital is the main factor which is directly responsible for many things in the organization. There are $82 \%$ of the studied industries reported that they are facing capital related problems in maintaining environmental measures. However the managements M/s Ch.Veerraaju\& co, Adaniwilmar, Sarvaraya Sugars are part of this .

Sponsoring tree plantation programmes are initiated by industries in the study region. Frequently they are engaging in these tree plantation programmes as part of their policies

NCS industries, GSK, Coromandel, Sri Venkatrama oil Indpvt ltd, ITC are among the leading industries in

Table 14Response on the promotion of tree

Table 15.Observation on Environmental Impact Assessment

\begin{tabular}{lll}
\hline & Yes & No \\
\hline No. of Industries & 21 & 7 \\
Percentage & 75 & 25 \\
\hline
\end{tabular}

sponsoring tree plantation programmes. Sri Ramadas paper ltd, Sri Ramalingeswara Paper products pvt ltd are not contributing in tree plantation programmes.

The study report observed that majority of the industries are doing environmental impact assessment periodically. Among them, Sarvaraya sugar bottling unit, GSK, ITC, Coromandel international, NCS

Table 16.Response on the staff exposure trips to sanctuaries/ Coringa wildlife

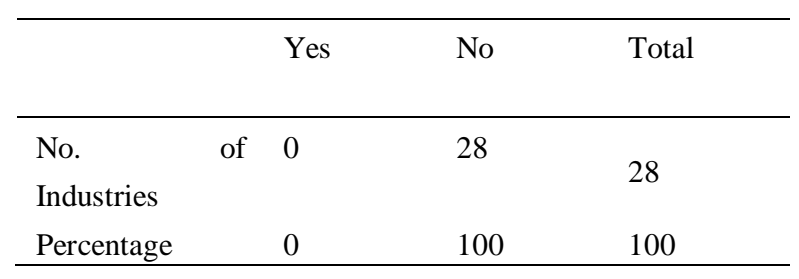

industries and some of them are not doing environmental impact assessment are Sri papers, M/s Ch.Veerraju\& co, Sri Ramalingeswara paper products pvt ltd, Sri Venkatrama Oil Indpvt ltd

It is observed that all the industries are not considering staff exposure trips to sanctuaries or coring wildlife sanctuary so far. It is at the discretion of managements and yet to implement.

\section{Test 1. Independence of Nature of Industry and Eco- friendly practices.}

H01: The ability of the industry to honor the Ecofriendly practices is independent of the nature of Industry. In other words, an entity can follow Ecofriendly practices irrespective of its nature (or) type.

H11: The ability to honor Eco-friendly practices is not unique for all industries in EGREE region. It depends on type of industry to which it belongs.

Table 17.1. Observed Frequencies

\begin{tabular}{|c|c|c|c|c|}
\hline & \multicolumn{3}{|c|}{ Eco - Friendly Practices } & \multirow[t]{3}{*}{ Total } \\
\hline & Waste & 3 & Energy & \\
\hline & Management & R's & conservation & \\
\hline Agri- & 12 & 1 & 0 & 13 \\
\hline \multicolumn{5}{|l|}{ Industry } \\
\hline Fertilizers & 10 & 5 & 1 & 16 \\
\hline Food \& & 8 & 2 & 0 & 10 \\
\hline \multicolumn{5}{|l|}{ Beverages } \\
\hline Paper \& & 12 & 6 & 2 & 20 \\
\hline others & & & & \\
\hline Total & 42 & 14 & 3 & 59 \\
\hline
\end{tabular}


Table 17.2. Expected Frequencies

\begin{tabular}{|c|c|c|c|c|}
\hline & \multicolumn{3}{|c|}{ Eco - Friendly Practices } & \multirow[t]{2}{*}{ Total } \\
\hline & $\begin{array}{l}\text { Waste } \\
\text { Management }\end{array}$ & $\begin{array}{l}3 \\
\text { R's }\end{array}$ & $\begin{array}{l}\text { Energy } \\
\text { conservation }\end{array}$ & \\
\hline $\begin{array}{l}\text { Agri- } \\
\text { Industry }\end{array}$ & $9 *$ & 3 & 1 & 13 \\
\hline Fertilizers & $11 @$ & 4 & 1 & 16 \\
\hline $\begin{array}{l}\text { Food \& } \\
\text { Beverages }\end{array}$ & 7 & 2 & 1 & 10 \\
\hline $\begin{array}{l}\text { Paper \& } \\
\text { others }\end{array}$ & 14 & $5 \#$ & 1 & 20 \\
\hline Total & 42 & 14 & 3 & 59 \\
\hline $\begin{array}{c}\text { In the above } \\
\quad(R T * C \\
R T=\text { Row to } \\
E f=\text { Expect } \\
/ G T \\
* \text { is compute } \\
\text { @ is comput } \\
\text { \# is compute }\end{array}$ & $\begin{array}{l}\text { able expected val } \\
/ G T \text {. } \\
\text { al, } C T=\text { Column } \\
\text { l Frequency of a } \\
\text { as Row total } 13 \\
\text { d as Row total } 16 \\
\text { as } 20 * 14 / 59\end{array}$ & $\begin{array}{l}\text { les are } \\
\text { otal a } \\
\text { ell = ? }\end{array}$ & $\begin{array}{l}\text { mputed using th } \\
\text { GT = Grand Tot } \\
\text { t cells } R T * \text { That } \\
\text { otal } 42 / \text { Grand } \\
\text { total } 42 / \text { Grand }\end{array}$ & $\begin{array}{l}\text { formula } \\
\text { cells CT } \\
\text { otal } 59 \\
\text { Total } 59\end{array}$ \\
\hline
\end{tabular}

The calculated value for chi-square is 9.30 . It is lower than the critical value of chi-square at $5 \%$ significance level of 12.592. Thus it means that there is no significant difference between Observed frequencies and Expected frequencies. Hence we accept the H01 ( Null hypothesis) and conclude that nature of industry is not deciding the ability to contribute to eco-friendly practices in the 28 Industries under EGREE region.

Test 2. Independence of Size of Industry and Ecofriendly practices.

H02: The ability of the industry to honor the Ecofriendly practices is independent of the size of Industry. In other words an entity can follow Eco-friendly practices irrespective of its it is large scale or small scale.

H12: The ability to honor Eco-friendly practices is not unique for all industries in EGREE region. It depends on size of industry i.e large scale or small scale.

Table 18.1. Observed Frequencies

\begin{tabular}{lllll} 
& \multicolumn{2}{l}{ Eco - Friendly } & \multirow{2}{*}{ Tractices } & \\
\cline { 2 - 4 } & Waste & 3 & Energy & \\
& Management & R's & conservation & \\
\hline $\begin{array}{l}\text { Large } \\
\text { scale }\end{array}$ & 28 & 7 & 2 & 37 \\
Medium & 10 & & & \\
scale & & 6 & 1 & 17 \\
Small & 4 & & & 5 \\
scale & & 1 & 0 & 59 \\
Total & 42 & 14 & 3 & \\
\hline
\end{tabular}

Table 18.2. Expected Frequencies

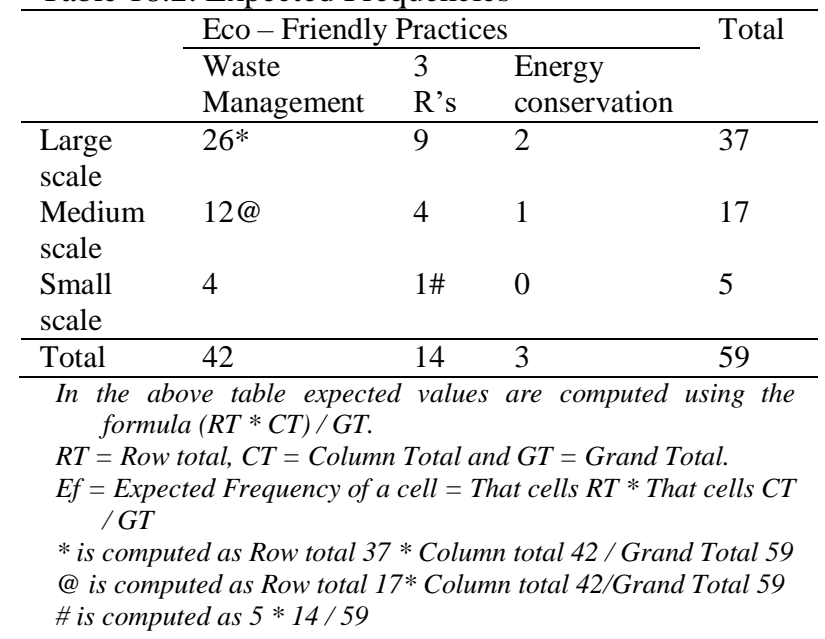

The calculated value for chi-square is 1.92 . It is lower than the critical value of chi-square at $5 \%$ significance level of 9.49. Thus it means that there is no significant difference between Observed frequencies and Expected frequencies. Hence we accept the H02 (Null hypothesis) and conclude that size of industry is not deciding the ability to contribute to eco-friendly practices in the 28

Table - 18.3Calculation of Chi-Square value

\begin{tabular}{|c|c|c|c|c|}
\hline $\mathrm{O}_{\mathrm{f}}$ & $\mathrm{E}_{\mathrm{f}}$ & $\left(O_{f}-E_{f}\right)$ & $\left(\mathrm{O}_{\mathrm{f}}-\mathrm{E}_{\mathrm{f}}\right) 2$ & $\begin{array}{l}\left(\mathrm{Of}-\mathrm{E}_{\mathrm{f}}\right)^{2} \\
/ \mathrm{E}_{\mathrm{f}}\end{array}$ \\
\hline 28 & 26 & 2 & 4 & 0.15 \\
\hline 10 & 12 & -2 & 4 & 0.33 \\
\hline 4 & 4 & 0 & 0 & 0 \\
\hline 7 & 9 & -2 & 4 & 0.44 \\
\hline 6 & 4 & 2 & 4 & 1 \\
\hline 1 & 1 & 0 & 0 & 0 \\
\hline 2 & 2 & 0 & 0 & 0 \\
\hline 1 & 1 & 0 & 0 & 0 \\
\hline \multirow[t]{2}{*}{0} & 0 & 0 & 0 & 0 \\
\hline & & & Total & 1.92 \\
\hline $\begin{array}{l}O_{f} \\
E f \\
C l \\
T h\end{array}$ & $\begin{array}{l}\text { rved } \\
\text { cted } \\
\text { e val } \\
\text { val }\end{array}$ & $\begin{array}{l}\text { cies } \\
\text { ies } \\
\text { im }\left(\left(O f-E_{f}\right.\right. \\
\text { Chi-square }\end{array}$ & $\begin{array}{l}\left./ E_{f}\right)=1.92 \\
\text { at } 4 \text { dof }=\end{array}$ & 9.49 at $5 \%$ \\
\hline
\end{tabular}

Industries under EGREE region.

\section{CONCLUSION AND RECOMMENDATION}

\section{Conclusion}

Results of the analysis and observations during the field visit provided ample evidence to conclude on ecofriendly practices of select industries where majority of the industries are using systematic ways to discharge solid waste out of the process as per norms and recommendations Pollution Control Board. 
(2) Green cover practices was that most of the industries are maintaining effluent treatment plants for the liquid waste and recycled water is used for the tree plantation. Industry managements have been implementing ecodevelopment committees and bio-diversity committees for maintaining the flora and fauna. Some companies started ground water recharge points within the premises of the organization and also in the nearby villages.

(3) Renewable energies utilization indicated that very few industries are harvesting the solar energy for the plant and utilizing it to some extent. But vivid measures for utilization of the solar energy are to be augmented. In some companies like ITC biofuel consumption is $80 \%$ and remaining $20 \%$ is Coal. Study revealed that out of 28 Industries only three industries were using solar energy systems to generate power for administrative and other selected purposes.

(4) Environmental protection awareness programmes are noticed at various industries. Industries are conducting lectures and competitions on account of environmental protection programs.

(5) As part of the corporate social responsibility, most of the industries are contributing to the education, followed by plantation of trees as a part of their CSR initiatives. Many industries are engaged in multiple activities, so activity engagement ratio was found to be 1.71 activities per industry..

(6) Study does not indicate any significant innovations made by these industries. However, initiatives in terms of ground water recharge, a steady progress towards renewable energies utilization and efforts in development of green belts should be cherished.

(7) The study indicates that the practices of three industries ITC, Coromandel and GSK can be bench marked by all other industries to the reach optimum levels in eco-friendly industry practices.

(8) There are 18 industries constituting $64 \%$ of total industries in the region are providing adequate education on need for protection of environment. Study also reveals that there are 6 industries $(22 \%)$ had carried out such programs to certain extent but not on regular basis or not of having a significant impact factor for such programs.
(9) Factor dependency test performed for independency in respect of nature and size of industries in the select region and their eco-friendly practices gave the result that ability to undertake eco-friendly practices is not connected the nature and size of the organisation. The computed chi-square values are lower than critical values for chi-square at 5\% significance level.

\section{Recommendations}

(1) Government and policy makers have to make special provisions for disposal of Industrial waste at least for small and medium enterprises (SME).

(2) Government should standardize and mandate disclosure rules such that all industries irrespective of its nature and size should disclose all matters concerning environment on quarterly basis.

(3) HRD wing should conduct training classes to employees in eco-friendly practices with emphasis on $3 R$ 's and reward / patent the innovations received from industries. Further, priority should be given to Energy conservation is the major area where improvement is immediately needed.

\section{REFERENCES}

Albu, L., Popescu, M., Deselnicu, V., Eugen, A., \& Gabriel, Z. (2010). Study and Practice on Alternative Eco-Friendly Processes for Leather Manufacture.

Aragon, A., Martí́, I., \& Hurtado, N. E. (2016). Proactive Environmental Strategies and Employee Inclusion: The Positive Effects of Information Sharing and Promoting Collaboration and the Influence of Uncertainty.

Banerjee, S. B., Iyer, E. S., \& Kashyap, R. K. (2003). Corporate environmentalism: antecedents and influence of industry type. J. Mark.

Bansal, P., \& Roth, K. (2000). Why companies go green: a model of ecological responsiveness. Manag: Acad.

Barla, P. (2007). ISO 14001 certification and environmental performance in Quebec's pulp and paper industry. J. Environ, 291-306.

Bowen, F. E. (2000). Environmental visibility: a trigger of green organizational response? Environ. 
China, T. A., Tatb, H. H., \& Sulaimana, Z. (2015). Green Supply Chain Management, Environmental Collaboration and Sustainability Performance.

Choi , D., \& Hwang, T. (2015). The impact of green supply chain management practices on firm performance: the role of collaborative capability.

Darnall, N., Henriques , I., \& Sadorsky, P. (2008). Do environmental management systems improve business performance in an international setting? J. Int, 364-376.

Darnall, N., Henriques, I., \& Sadorsky, P. (2009). Adopting proactive environmental practices: the influence of stakeholders and firm size. Manag.

Dasgupta, S., Hettige, H., \& Wheeler, D. (2000). What improves environmental performance? Evidence from Mexican industry. J. Environ, 39-66.

Demirel, P., \& Kesidou, E. (2011). Stimulating different types of eco-innovation in UK: government policies and firm motivations. 1546-1557.

Gangadharan, L. (2006). Environmental compliance by firms in the manufacturing sector in Mexico.

Horbach, J. (2008). Determinants of environmental innovation - new evidence from German. Panel data sources. Res. Policy 37.

Jang, E. K., Park, M. S., Roh , T. W., \& Han, K. J. (2015). Policy Instruments for Eco-Innovation in Asian Countries. 7.

Johnstone, N., \& Labonne, J. (2009). Why do manufacturing facilities introduce environmental management systems? Improving and/or signaling performance. Ecol.

Lepoutre, J., \& Heene, A. (2006). Investigating the impact of firm size on small business social responsibility: a critical review. J. Bus. Ethics $67,257-273$.

Liu, X., Liu, B., Tomohiro, S., Yu, Q., Bi, J., \& Fujitsuka, T. (2010). An empirical study on the driving mechanism of proactive corporate environmental management in China. $J$. Environ, 1707-1717.

Lopez-Gamero, M. D., Molina-Azorin, j. F., \& ClaverCortes, E. (2009). The whole relationship between environmental variables and firm performance: competitive advantage and firm resources as mediator variables. J. Environ, 3110-3121.

Madhu, K., George, D., \& Ramirez , H. D. (2009). Adoption of pollution prevention techniques: The role of management systems and regulatory pressures.44,.

Motta, R. S. (2006). Analyzing the environmental performance of the Brazilian industrial sector. Ecological Economics. 57(2006).

Ryszko, A. (2016). Proactive Environmental Strategy, Technological Eco-Innovation and Firm Performance-Case of Poland.

Sangle, S. (2010). Empirical analysis of determinants of adoption of proactive environmental strategies in India. J. Bus, 51-63.

Singh, N., Jain, S., \& Sharma, P. (2014). Determinants of proactive environmental management practices in Indian firms: an empirical study. $J$. Clean, 469-478.

The intrinsic features of Carruthers, $G$ and Vanclay, F. (2012). Environmental Management Systems that facilitate adoption and encourage innovation in primary industries. J. Environ, 125-134.

Weng, H.-H., Chen, J.-S., \& Chen , P.-C. (2015). Effects of Green Innovation on Environmental and Corporate Performance: A Stakeholder Perspective. 7, sustainability. 